\title{
Addressing contract cheating in Kosovo and international practices
}

\author{
Sabiha Shala, Mimoza Hyseni-Spahiu* (D) and Afrim Selimaj
}

\author{
* Correspondence: mimoza. \\ hysenispahiu@unhz.eu \\ University of Haxhi Zeka, Peja, \\ Kosovo
}

\begin{abstract}
Although there is much research on the contract cheating phenomenon, there is very little research on the legal solutions available to address such problems and almost zero research on the contract cheating phenomenon specifically in Kosovo in the Western Balkan region. This article presents the current situation with regard to contract cheating in Kosovo and compares it to western countries, with the aim of identifying the best international practices for combating contract cheating. We also present the results of a study we conducted which suggest that the term "contract cheating" is not well defined in university legal documents, nor is there a consistent understanding of what constitutes contract cheating. Consequently, the perpetrators are not being punished. Results from our online survey also show that $5 \%$ to $20 \%$ of students use contract cheating services, and they are paying an estimated fee of between 100 and 200 euros and in some cases, more than 250 euros.
\end{abstract}

Keywords: Contract cheating, Practices of western countries, Western Balkan countries

\section{Introduction}

Contract cheating is one of the most serious threats to quality education, and negatively impacts workplace professionalism and society as a whole, regardless of location. All Higher Education Institutions (HEI) face this phenomenon and have to address it. Thus far, the problem of contract cheating has been raised mainly through media reports and civil society (Krasniqi 2015; Bytyçi 2017). There is no specific research on contract cheating and only a few research papers that indirectly consider contract cheating (Kosumi and Leka 2018). Moreover, there is no research or data specific to Kosovo.

The aim of this research is to present the current situation with regard to the contract cheating problem in Kosovo and compare it to the situation in western countries. In doing so, we aim to identify the best international practices for combating contract cheating, focusing on legal solutions, including legislation, HEI statutes, and study regulations. The importance of the present research is twofold: firstly, it will be the first research conducted on contract cheating specifically in Kosovo, and secondly, the research method is unique in this context. The researchers developed a questionnaire

(c) The Author(s). 2020 Open Access This article is licensed under a Creative Commons Attribution 4.0 International License, which permits use, sharing, adaptation, distribution and reproduction in any medium or format, as long as you give appropriate credit to the original author(s) and the source, provide a link to the Creative Commons licence, and indicate if changes were made. The images or other third party material in this article are included in the article's Creative Commons licence, unless indicated otherwise in a credit line to the material. If material is not included in the article's Creative Commons licence and your intended use is not permitted by statutory regulation or exceeds the permitted use, you will need to obtain permission directly from the copyright holder. To view a copy of this licence, visit http://creativecommons.org/licenses/by/4.0/. The Creative Commons Public Domain Dedication waiver (http://creativecommons.org/publicdomain/zero/1.0/) applies to the data made available in this article, unless otherwise stated in a credit line to the data. 
to obtain primary data from students, academic staff and alumni about contract cheating acts. The researchers then applied a comparative approach, bringing together information from Kosovo and other countries in order to identify better preventative measures, focusing on legal measures. We also conducted informal interviews with HEI managerial staff and undertook an extensive literature review.

In order to propose a comprehensive and appropriate approach for combating contract cheating in HEIs in Kosovo, the following research questions are addressed in the present research:

1. What is the current situation in Kosovo with regard to contract cheating?

2. Are there any legal measures put in place by HEIs in Kosovo to combat contract cheating?

3. Can a new approach be implemented in Kosovo, considering the local context?

In answering these questions, two main hypotheses are confirmed: i) HEI policies and legislation in Kosovo need to be further improved in order to combat and prevent contract cheating effectively; ii) Kosovo's HEIs lack detailed legal definitions of the term contract cheating, and lack specific administrative and other mechanisms that may detect and prevent contract cheating.

\section{Literature review}

Kosovo's HEIs have sanctions in place for plagiarism, and support the right of authorship; however, contract cheating is only superficially regulated in their legal documents, which include statutes, internal academic regulations, code of ethics, as well as the Law on Higher Education (Shala et al. 2018, AAB College 2020, UBT College 2020, University of Mitrovica Isa Boletini 2019, University of Mitrovica Isa Boletini 2020, University of Applied Science 2019, University of Prizren 2020, University of Haxhi Zeka 2019, University of Gjakova 2020, University of Kadri Zeka 2020). Compared to western countries' HEIs (Newton 2018; Medway et al. 2018; Bretag et al. 2019), Kosovo's HEIs lack detailed legal definition of the term contract cheating, and lack specific administrative and technical mechanisms that may detect and prevent contract cheating, making it difficult to prohibit these illegal practices (Shala et al. 2018). The legislation and code of ethics that do exist only consider and provide mechanisms to address plagiarism cases (Shala et al. 2018), and contract cheating is only indirectly prohibited by the internal academic regulation regarding cheating in general (Shala et al. 2018, AAB College 2020, UBT College 2020, University of Mitrovica Isa Boletini 2019, University of Mitrovica Isa Boletini 2020, University of Applied Science 2019, University of Prizren 2020, University of Haxhi Zeka 2019, University of Gjakova 2020, University of Kadri Zeka 2020).

There are several definitions of the term contract cheating in the international literature. Stoesz et al. (2019) describe contract cheating as an act that occurs when students outsource their academic work to a third party. In their definition, contract cheating is when a third party produces or completes academic work for a student, which is then presented by that student as their own. A student might have a personal connection to this person or pay a fee to the third party (Stoesz et al. 2019; Lancaster 2020; Foltýnek and Králíková 2018; Eaton et al. 2019). Medway et al. state that contract cheating 
providers attempt to manipulate students by normalizing the cheating behaviour, and "lure [them] into transactions" using various techniques (2018, p. 23). For our research, we have adopted Rigby et al.'s (2015) definition of contract cheating as an activity that involves a monetary transaction between a student and the provider of such service. For example, contract cheating is deemed to occur when a student hires someone to compose their written work, and then submits that work as their own for university credit.

As stated above, the policies and legislation of Kosovo's HEIs do not provide specific measures and mechanisms to prevent or combat contract cheating activities. Contract cheating cases are addressed and dealt with through the mechanisms and measures intended to prevent and combat plagiarism in general. In the rare case of contract cheating being reported and ending up in the national courts, the courts have failed to identify a criminal offense due to the lack of adequate legal provisions to do so (Boletini and Molliqaj 2017). Our research into international experiences has identified that few countries' current laws tackle contract cheating. The UK, Ireland and Australia have indicated that they are considering creating legal measures to specifically identify contract cheating as an illegal service, but only New Zealand has enacted legislation doing so, effective since 1989 (Draper and Newton 2017). Notably, however, New Zealand does not specifically define the term contract cheating, nor identify its intent (Draper and Newton 2017). Other scholars have also considered the possibility of a legal solution to address contract cheating but only with regard to companies and those who provide the services (Draper and Newton 2017). The authors agree with Amigud and Dawson (2020) that there is lack of legal measures or solutions available to address contract cheating, possibly due to a lack of evidence on the occurrence of contract cheating cases. In any case, Draper and Newton are optimistic about this avenue of tackling contract cheating and encourage countries to work on creating or improving appropriate laws (Draper and Newton 2017).

With regard to evidence of the number of (self) reported contract cheating cases, data differs from country to country. According to existing research, this number ranges from $3.5 \%$ to $22 \%$, differs from year to year, and appears to be increasing (Foltýnek and Králíková 2018; Medway et al. 2018). According to Newton (2018), the percentage of students admitting to paying someone else to undertake their work increased from $3.5 \%$ in 2014 to $15.7 \%$ in 2018 , potentially representing 31 million students around the world.

The price of written work also differs from country to country. Students in the UK reported paying up to $£ 277$ for a first-grade essay (Rigby et al. 2015). On his author website, Lancaster (2018) presents different figures and states that there are companies that won't even start work before the student makes a down payment of $£ 800$. According to the same author, the typical service offered by a UK-based organisation costs $£ 275$ with potential discounts available (2018). It has been reported that, after the student graduates, the service provider has then administered an additional fee - much like extortion (European Network for Academic Integrity 2020). However, these companies are not the only actors involved in contract cheating - students are turning to their colleagues or family members too.

There are many reasons why students resort to contract cheating, including for example, a belief that they do not possess the academic writing skills required to 
complete a particular assignment. However, poor teaching and assessment methods also play a role (Eaton et al. 2019; Foltýnek and Králíková 2018, Bretag and Mahmud 2016), as Bretag et al. (2018) argued in their research paper "Contract cheating and assessment design: exploring the relationship". In Kosovo, similar comparison data is scarce and can only be found in some public reports and media outlets; there is no scientific data focusing on contract cheating. Therefore, we assert that this present research is the first to offer a comprehensive understanding of the situation within the Kosovo context.

\section{Methodology}

Data was collected via informal interviews with managerial HEI staff and an online questionnaire using Google forms. The informal interviews sought to gather official data about reported contract cheating cases and to gauge the staff's assessment of their HEI's academic rules around contract cheating. In Spring 2020, the online survey instrument was shared with Kosovar students, graduates and academic staff through emails, Facebook and other social networks. The total number of respondents was 400 . This method helped us to gather data anonymously and directly from the students, graduates and academic staff, and consequently encouraged students to self-report contract cheating behaviours.

The collected data were processed mainly through SPSS statistics program, with only the answers to the open questions analysed in Word documents. The results are presented in table format and as percentages, except for the answers to the open questions. The answers to the open questions were content-analysed and sorted into categories according to the type of response given.

The online questionnaire itself was designed to be short and simple. It contains 16 questions addressing demographics, profession, awareness about the definition of contract cheating, contract cheating activities, reasons why students use contract cheating services, and measures to be taken against the problem. There was only one open question; for all the other questions, respondents had to select one (or more) of the listed answers.

\section{The results of the research}

\section{Demographic and other general data}

The online questionnaire was sent to 600 potential participants and the authors received 400 responses. The participants were between 20 and 65 years old, and $73 \%$ of them were between 20 and 30 years old. More than half of them were women (59.8\%). More than half of the respondents were students (66.8\%), 19.8\% were academic staff, and $13.5 \%$ were graduates. Most of the participants (59.6\%) were studying law, economics and political sciences, $10.5 \%$ of them exact science (physics, chemistry, etc.), and the rest were studying in other fields.

\section{Awareness about contract cheating}

This section of the questionnaire posed questions that helped the authors gather information on awareness about contract cheating and its effects on the respondents. In response to the question about whether respondents were informed about contract 
cheating, overall, 38.9\% said that they had a good grasp of what this entailed, $29.9 \%$ said that they had a poor understanding, and $31.2 \%$ said they had no knowledge at all (see Fig. 1a).

After completing the questionnaire, most of the respondents said that they had a better understanding of contract cheating and its consequences, and approximately $17 \%$ maintained that they had only a moderate understanding (see Fig. 1b). When the questionnaire was distributed, additional explanations were given regarding the definition of contract cheating.

Respondents were asked if they were aware of any cases in Kosovo of students paying a third party to work on their diploma thesis, seminar paper, presentation or assignment: 38\% responded "yes," 30\% responded "no," and the rest said they did not know if there were cases (see Fig. 2).

Responding to the question regarding the percentage of students using contract cheating services, 36.1\% answered that they didn't know what percentage of students

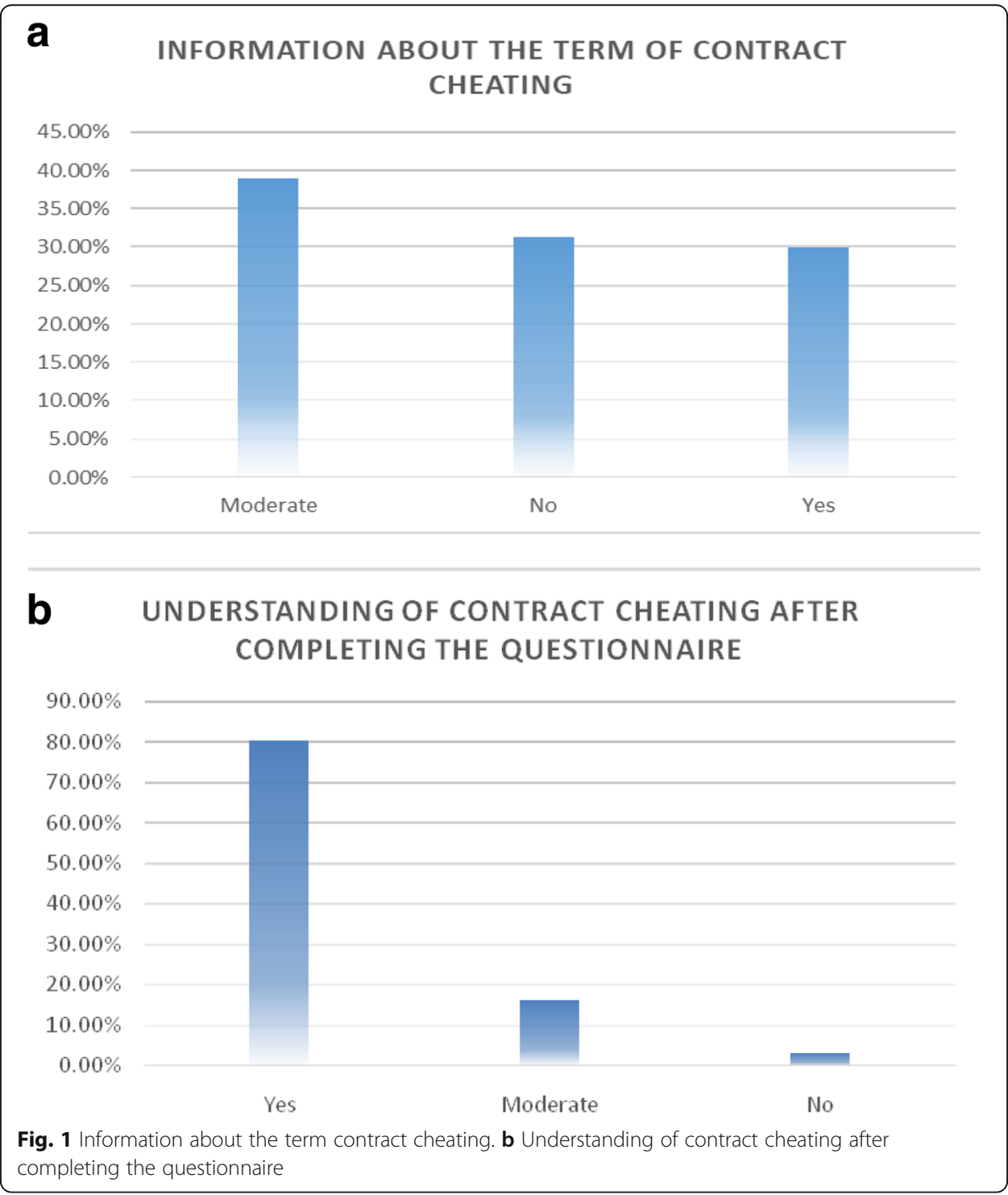




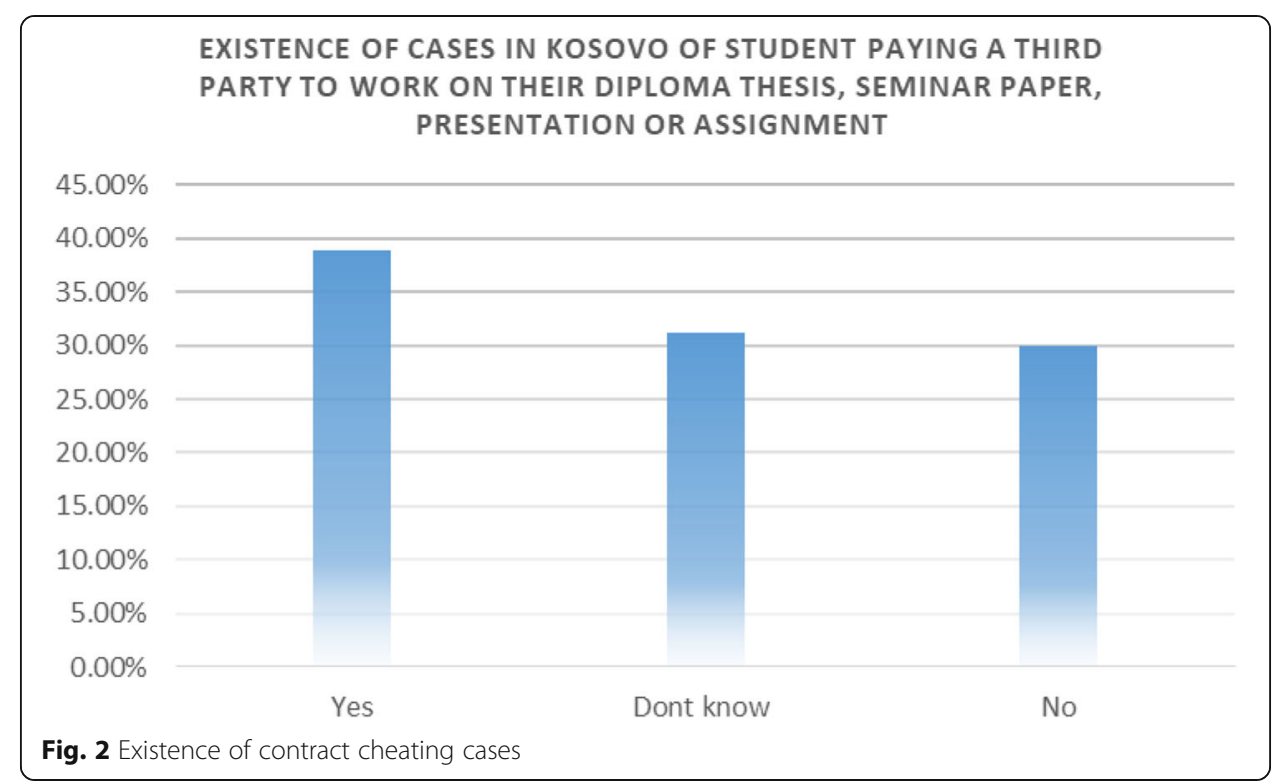

might be using these services, $19 \%$ said that they believed $5 \%$ to $20 \%$ of students used these services, and so on (see Fig. 3). These are the responses given by the participants, but it should be noted that responses may be inaccurate due to potentially feeling uncomfortable with telling the truth.

Almost all participants (85.2\%) did not know of any student who had paid a third party to prepare their written work for academic credit; only $14.3 \%$ indicated that they knew of students who had used such services (see Fig. 4).

Respondents were asked (Question 9) to provide more information about a particular case of contract cheating. Below are some of the responses that are content-analysed and sorted into categories according to the type of response given:

- I know a lot of cases.

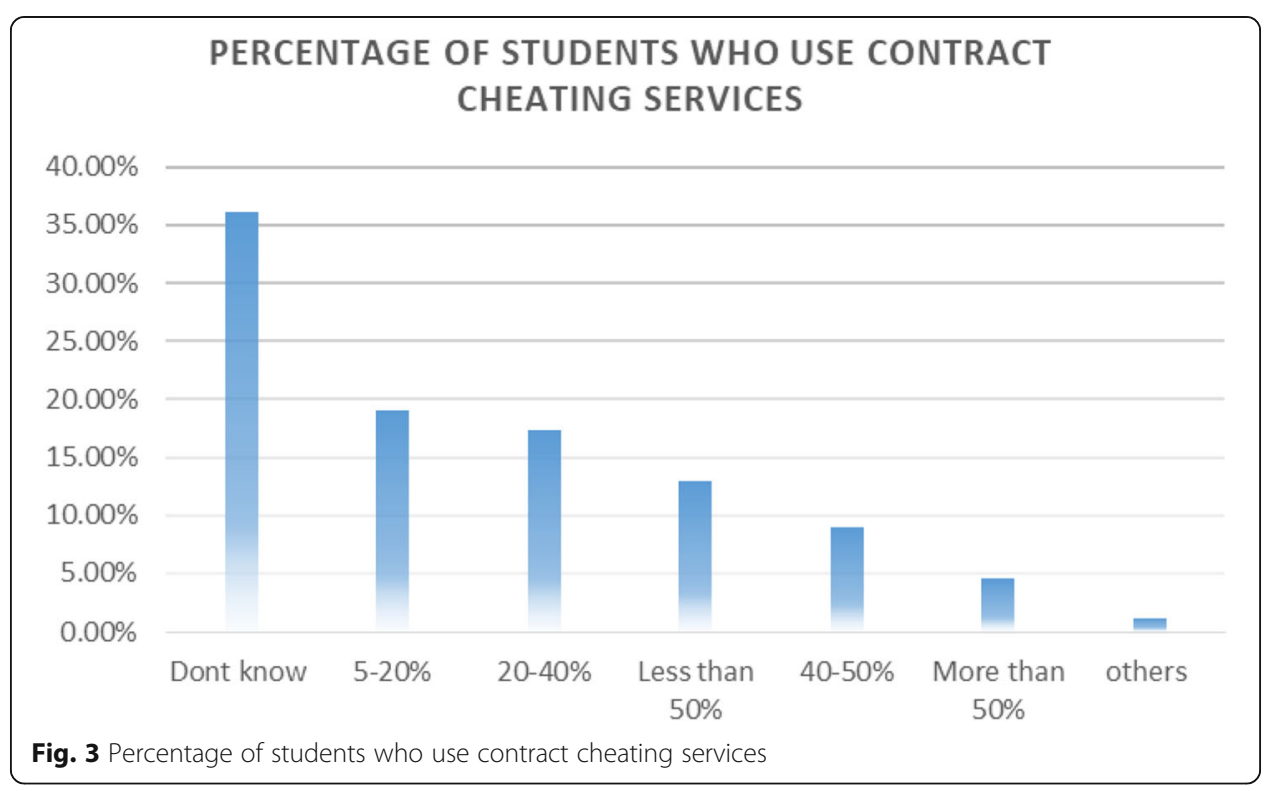




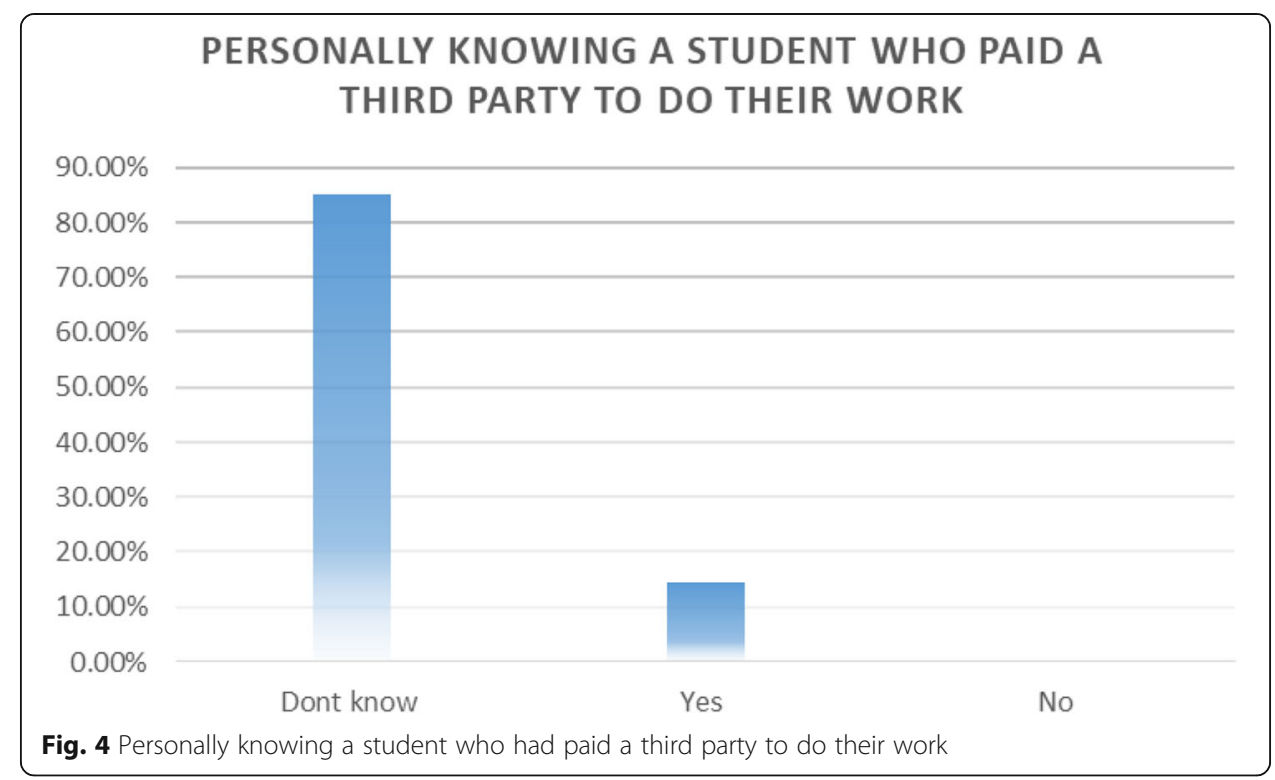

- I have heard about these cases but I do not have any concrete cases to mention as those people are acting very carefully in this regard. However, we know each other's capacities, at least those around us.

- I have read in instagram about the existence of a webpage that offers such services.

- At one party, I was closed to person who negotiated with someone about contract cheating. I can't give you more information, I'm sorry.

- I know students who prepare diplomas thesis in order to get money because they are unemployed and lack incomes.

- Students who have enough incomes do pay to a third person to prepare their thesis.

- I cannot mention names but I know some students who contracted a third person through Facebook and paid 200 euro, who got the thesis ready. The second case is when a student got the thesis from one professor.

- Offers to prepare thesis are shared in the student's Facebook group.

- I don't think it's ethical to mention the names of students who have paid diplomas.

- I do not have information.

\section{Price for contract cheating services}

More than half of the respondents did not have any idea of the amount of money that students pay for contract cheating services; only $18.9 \%$ thought that they pay between 100 and 200 euro, and few of them think that students pay more than 250 euro (see Fig. 5).

\section{Reported cases and reasons for using contract cheating services}

Respondents were asked if they were aware of any contract cheating cases that had been reported to their university, and if the university had taken any measures against them. Almost all respondents (90\%) answered that they did not have any information (see Fig. 6). 


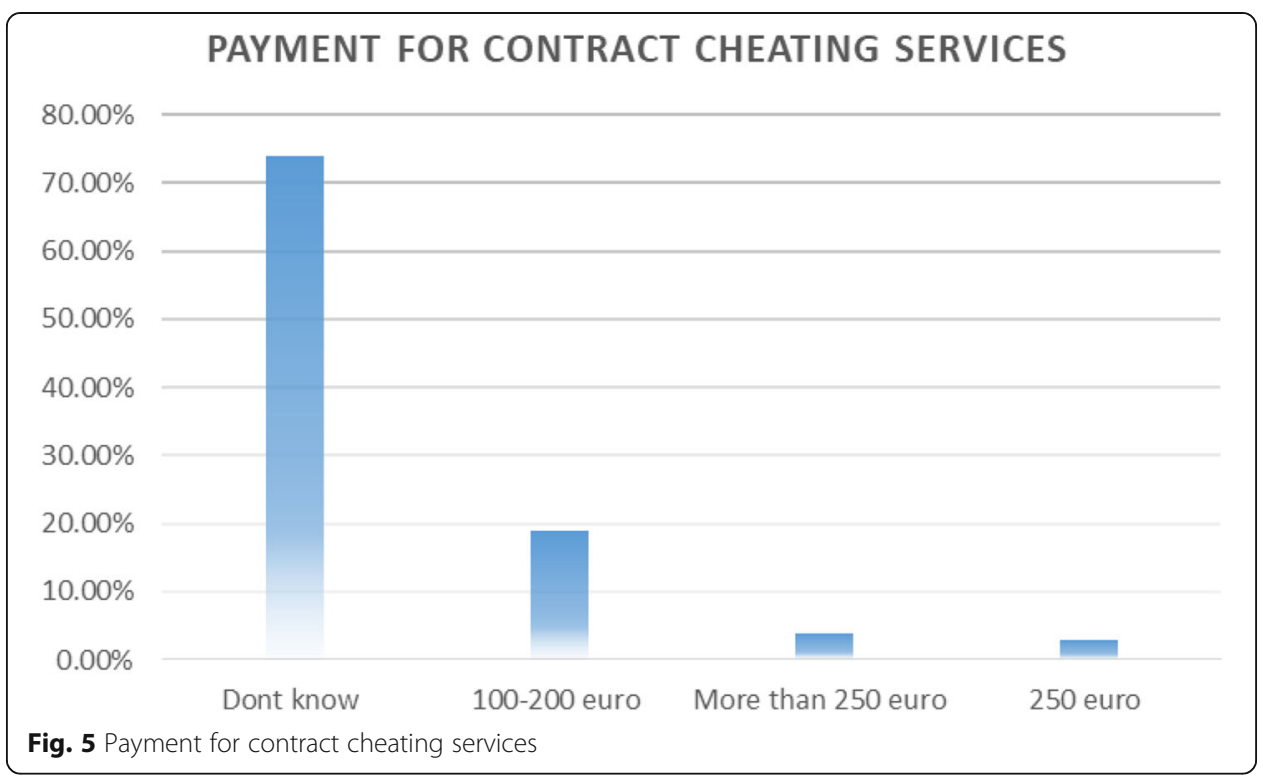

Around $40 \%$ of participants thought that students who use such services do not know that these activities are indirectly prohibited by the HEI's legal frameworks, and $22.7 \%$ of them thought that assessment methods within their university pushed students to use these services (see Fig. 7).

Almost all of the participants (87.4\%) thought that the people who provide these services should be punished; only $12.6 \%$ thought that they should not be punished (see Fig. 8).

Similar to the previous question, most of the participants $(89.5 \%)$ thought that the students who pay for such services should be punished (see Fig. 9).

Responding to the question about what the university/college needs to change in order to prevent such activities, almost half of the participants (40.9\%) thought that universities/ colleges should offer more training, $25.3 \%$ thought that universities should

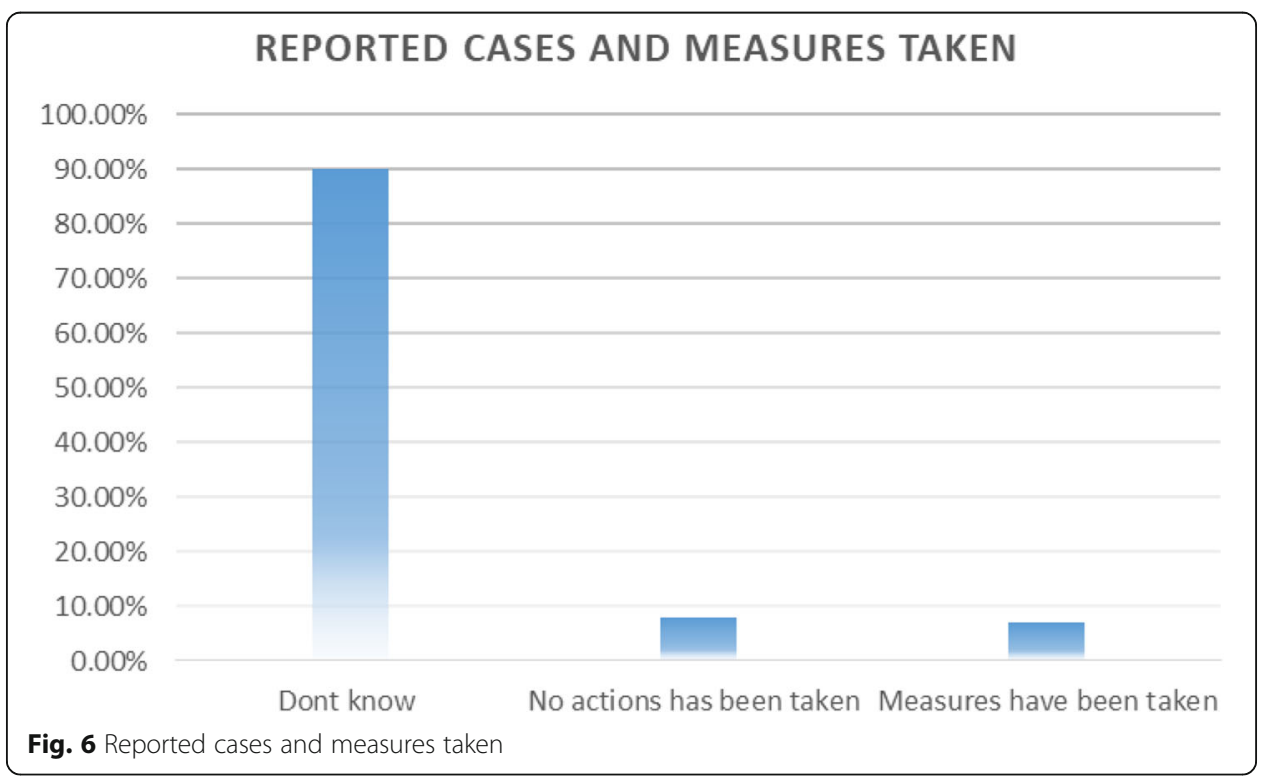




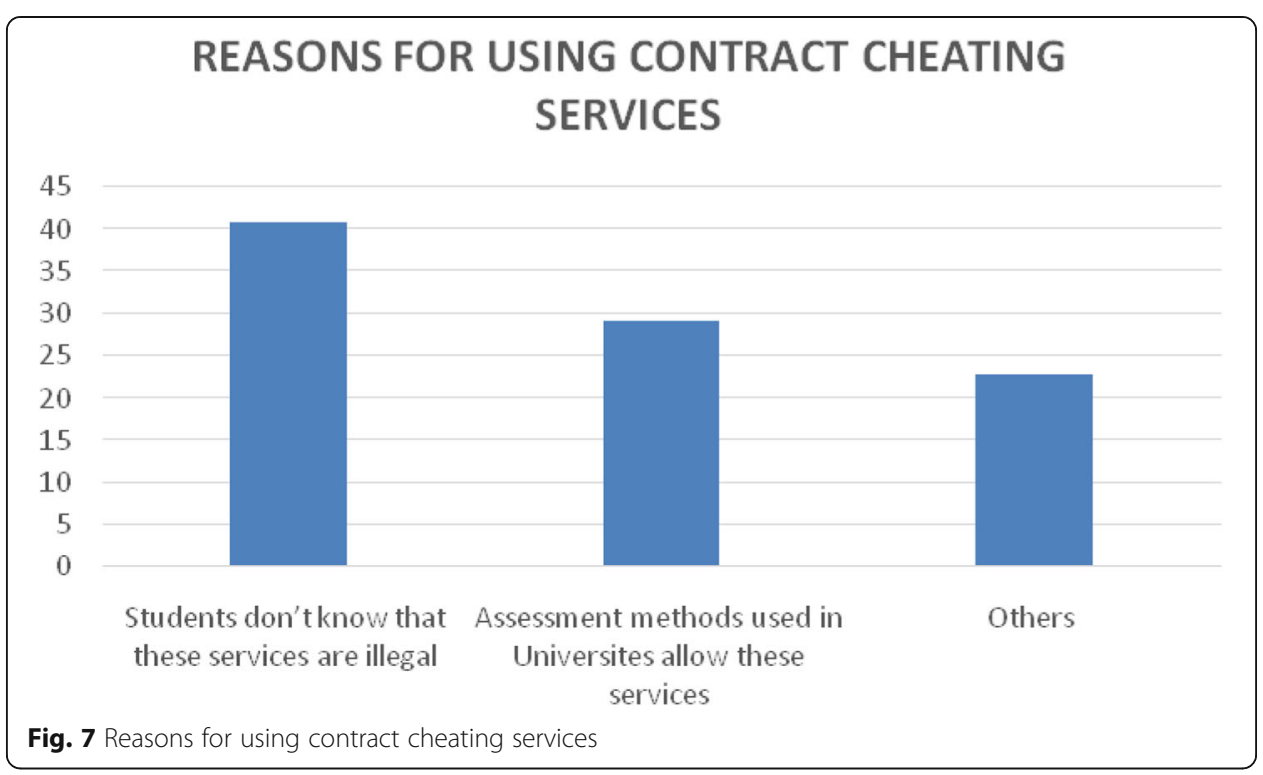

organize awareness campaigns, and $22.7 \%$ thought that universities should invest more in infrastructure (see Fig. 10).

Finally, it should be noted that the same questions were posed to all participants (teachers, graduates and students) and there were no significant differences in the responses between students and academic staff (all $p>0.05$ ). With regard to the informal interviews with HEI managerial staff, the questions were different and related to the number of reported contract cheating cases at their institutions. Most of them reported that there were no cases reported. A few confirmed that there were reported cases but that no measures had been taken against the service providers. In response to the questions about existing internal academic rules, respondents confirmed that there was no precise definition of contract cheating and no appropriate measures in place to counter this type of plagiarism.

\section{MEASURES AGAINTS PROVIDER OF CONTRACT CHEATING SERVICES}

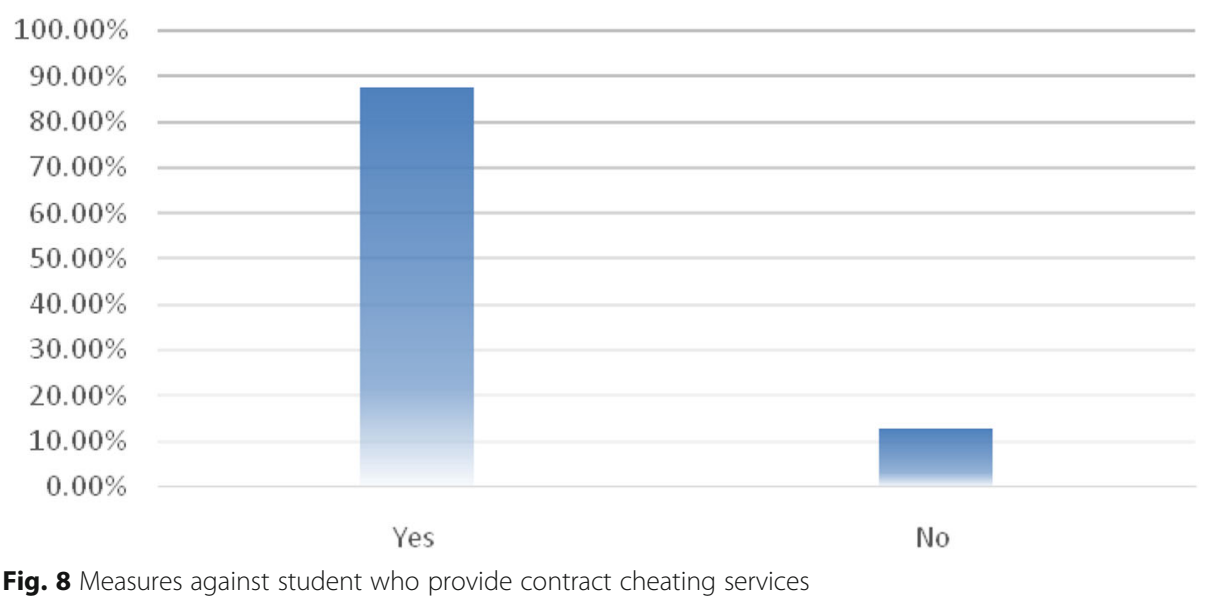




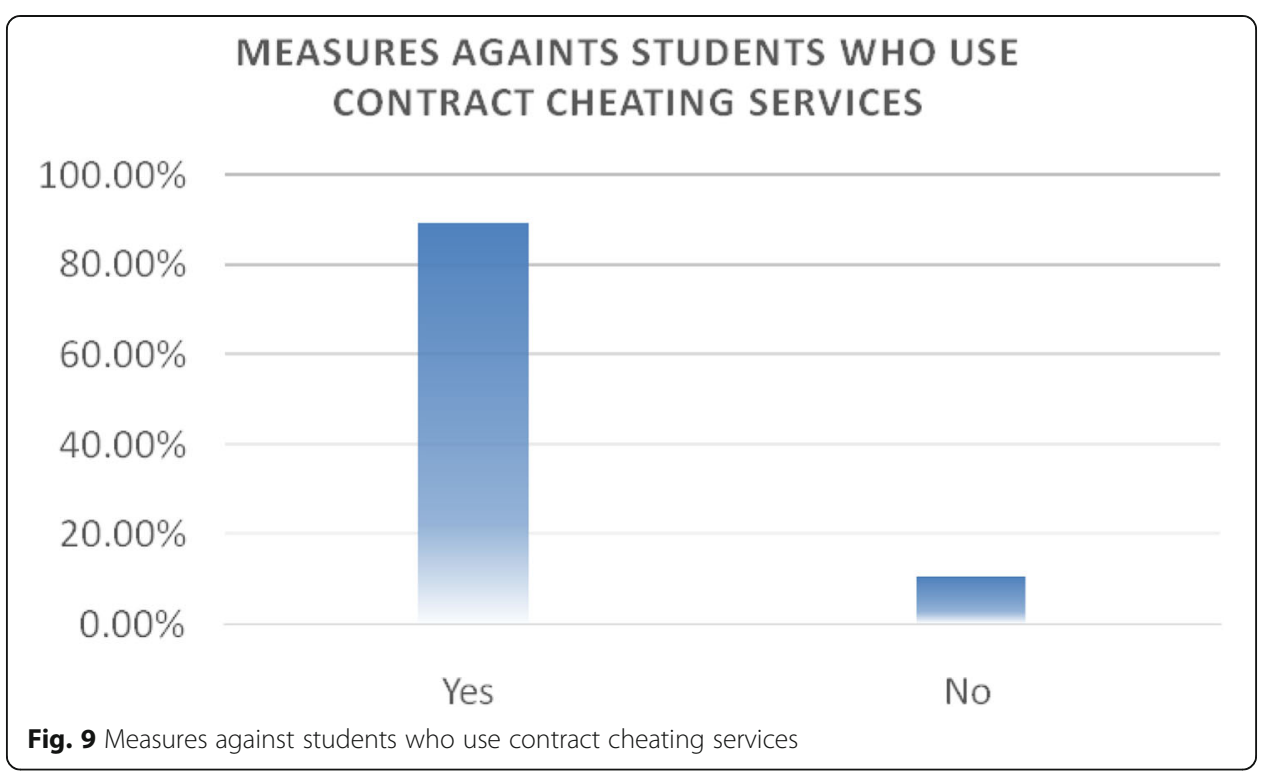

\section{Discussion}

Is contract cheating a matter of perception, or is it a real problem in Kosovo?

If we look only at the answers provided by the respondents and the very low number of reported cases (almost zero) (Boletini and Molliqaj 2017), contract cheating seems to be a possibly inaccurate perception rather than a real phenomenon. $36.1 \%$ of respondents answered that they weren't aware of any cases and couldn't give an exact figure of those students using such services. Moreover, almost all respondents (85.2\%) did not know any student personally or did not have evidence-based information about any student who had paid a third party to prepare their papers. Those who declared (14.3\%) that they had such information would not mention names, and none of them confirmed that they had reported such cases. Moreover, they considered it to be

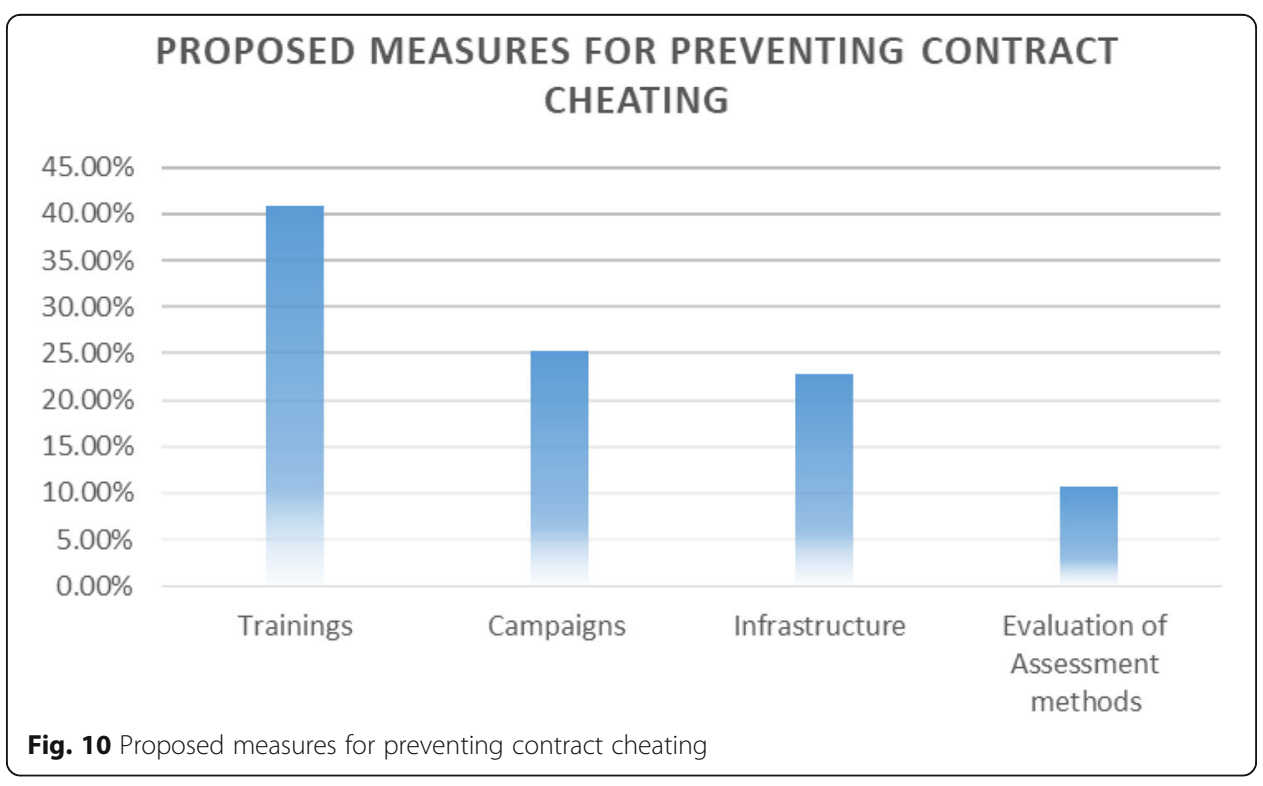


unethical behaviour to report such cases or to give more concrete information about those students involved in contract cheating activities. This is not the case in other countries - the percentage of self-reported contract cheating increased from 3.5\% in 2014 (Newton 2018) to 22\% in 2018 (Foltýnek and Králíková 2018). Of those cases that were reported in Kosovo, most were closed without the service providers being punished, due to the fact that the court could not find any provision within the Penal Code or any other legislation against which to punish them. As mentioned earlier, only the UK, Ireland, Australia and New Zealand have draft or actual legal provisions in place for contract cheating.

Despite the respondents' lack of awareness of actual cases, $61.2 \%$ thought that there were cases of contract cheating in Kosovo, and 19\% of them said that they believed that around $5 \%$ to $20 \%$ of students use these services.

\section{Awareness about the problem of contract cheating}

The lack of clear policies and legislation on contract cheating is a handicap. Students, academic staff and alumni indicated that they could not locate a clear definition of contract cheating in any of the existing policies and legislation in Kosovo. Instead, students commented that they came across this information through social media and television, or that they had heard directly from students who prepared theses for economic gain. At the beginning of the questionnaire, the respondents declared that they had moderate knowledge about contract cheating, but after completing the questionnaire $80 \%$ answered that they had a better understanding about contract cheating.

More than half of the respondents $(70 \%)$ did not have any idea about the amount of money students pay for such services; only $18.9 \%$ thought that students paid between 100 and 200 euro, and few of them thought that students paid more than 250 euro (Gazeta Blic 2018). One respondent stated that they were aware of one student having paid 500 euros. These figures are similar to the amount reported in the other countries as mentioned above (Rigby et al. 2015).

\section{Measures to address contract cheating}

It's clear that HEIs need to take measures to address contract cheating, considering the low number of reported cases, perpetrators going unpunished for those limited reported cases, weak knowledge about what constitutes contract cheating, and the estimation given by respondents that $5 \%$ to $20 \%$ of students are involved in contract cheating behaviours. In response to the question about whether HEIs should take measures against the students and the third party involved, almost all (90\%) respondents agreed that both students and providers of contract cheating services should be punished. As stated above, the problem in Kosovo is that the courts are not able to qualify contract cheating as a criminal act due to the lack of appropriate legal provisions. These provisions do not exist in almost any other countries' legislation either. However, researchers still recommend that countries continue to seek out legal courses of identification of and punishment for contract cheating.

Almost half of the respondents $(40.9 \%)$ indicated that they thought that education about contract cheating was the best way forward, while $25.3 \%$ prioritized awarenessraising campaigns, and $22.7 \%$ considered that anti-plagiarism tools were necessary, 
available to both academic staff and students. In contrast to research on contract cheating in other countries (Eaton et al. 2019; Foltýnek and Králíková 2018), only 10.6\% of the respondents in Kosovo thought that HEIs should revise their teaching and assessment methods. The relationship between contract cheating and assessment methods does exist and does have impact on this phenomenon (Bretag et al. 2018; Bretag and Mahmud 2016; Brimble 2016). Since 2002, Kosovan HEIs have been asked by the Ministry of Education to comply with the Bologna process. Since then, they have started to implement new assessment methods for evaluating students' work, such as written exams, research papers, etc. However, these institutions do not yet have the basic infrastructure in place to support these new ways of assessing, such as using detection plagiarism software, establishing institutional storage of student's written work, or national storage of theses (Shala et al. 2018), etc. The authors believe that Kosovan HEIs should also use more face-to-face assessment methods. Most of the survey respondents thought that all the above-mentioned measures should be considered by Kosovan HEIs and the authors agree.

\section{Conclusions and recommendations}

The contract cheating phenomenon is present in Kosovo as it is all over the world, and it is a real problem. The main problem is that the number of reported cases is very small or almost zero because people are not prepared to report such cases. It is necessary for each HEI to establish a specific reporting mechanism which can ensure anonymity for whistle-blowers. HEIs lack proper policies and legal provisions to define, prevent and combat contract cheating; therefore, it is necessary to revise those policies and legal provisions based on the practice of the other HEIs that have more advanced policies, and tailored to the circumstances of Kosovo. Kosovo HEIs also lack fully functional anti-plagiarism software to detect plagiarism which is one of the preconditions of international best practice for combating contract cheating. Therefore, they have to make anti-plagiarism software available to both academics and students.

Awareness-raising activities are almost non-existent and therefore HEIs should work towards organizing regular seminars, round tables, etc. The results of the survey prove that students, academic staff and alumni have a very superficial or no information about the contract cheating issue. Teaching and assessment methods should be appropriate and not push students to plagiarize and use contract cheating services to pass exams. Therefore, academic staffs of the HEIs in Kosovo need to work hard at designing appropriate assessment methods and tools as recommended below.

The following recommendations that are meant for HEIs in Kosovo, academicians, students and state institutions responsible for reviewing state policies and laws, are based on the experiences of the countries mentioned earlier, that do have legislation around contract cheating (either drafted or already in place), and also on the results from the online questionnaire. Based on the discussion above, HEIs in Kosovo need to take several measures to address the problem of contract cheating in a more efficient and effective way.

\section{Legal measures to address contract cheating}

Legal measures need to be established which clearly define what constitutes contract cheating, and better regulate the measures and procedures to be taken against students 
and the third parties involved in such cases. HEIs should define and include the term contract cheating in their internal legal acts (Statutes, Code of Ethic, Regulations for bachelor, master and doctoral studies). In their internal legal acts, HEIs should outline clear and concrete sanctions against students using contract cheating services, which sanction should also include some corrective education. The internal rules of HEIs should address also carefully the issue of the burden of proof meaning that the educational dishonesty should use "on the balance of probabilities", not "beyond reasonable doubt" (Sokol 2017). With regard to the providers of contract cheating services, relevant ministries of the Republic of Kosovo should amend the existing legislation in order to sanction contract cheating either through criminal law or other laws (law education act or law on commerce). It might be a completely new law which specifically addresses the contract cheating phenomenon.

\section{Additional non-legal measures}

In addition to the legal measures, HEIs in Kosovo should take other non-legal measures in order to better address this harmful phenomenon, including:

- Organising continuous awareness-raising activities which aim to make students and others aware about the problem of contract cheating, and its negative effects and consequences.

- All HEIs should invest in infrastructure that would technically help address the problem of contract cheating, for example buying a license for and using antiplagiarism software. The anti-plagiarism tool cannot fully address the problem of contract cheating on its own, but it can be helpful to professors in identifying plagiarised text that might be the result of contract cheating services.

- Teaching and assessment methods for students are very important and can contribute a lot towards addressing the contract cheating problem. Therefore, HEIs in Kosovo should use advanced and appropriate teaching and assessment methods to prevent contract cheating activities.

- HEIs in Kosovo should think about additional mechanisms that facilitate and encourage students and other parties to report contract cheating activities. A successful mechanism can be one that ensures anonymity of the potential whistleblowers.

\section{Appendix}

Questionnaire "Addressing the contract cheating at HEI and international practices" (The questionnaire is anonymous and the data collected will only be used as a statistical form for research on the above topic and there will be no personal level references)

1. What age group do you belong to?
$1.1 .18-20$
$1.2 .20-40$
$1.3 .40-60$

2. What is your gender?

2.1. Female

2.2. Male 
3. Are you?

3.1. Student

3.2. Professor

3.3. Graduate

4. What is your field of study?

4.1. Social sciences: economy, justice, literary, tourism

4.2. Exact sciences: physics, chemistry, math

4.3. Natural Sciences: Agriculture, environment etc.

5. Do you know about "contracts cheating" for the preparation of scientific papers

(diploma theses, seminar papers)?

5.1. Not at all

5.2. Slightly

5.3. Moderate

5.4. A lot

6. In your opinion, are there cases in Kosovo when students pay the third person to work on their diploma thesis, seminar paper, presentations, and assignments?

6.1. Yes

6.2. No

6.3. Very little

6.4. There are many cases

7. In your University / college in general, what do you think is the percentage of those students who use these services (pay) to earn academic credit through these works?

7.1. Less than $5 \%$

$7.2 .10 \%-20 \%$

$7.3 .20 \%-30 \%$

$7.4 .30 \%-40 \%$

7.5. More than $50 \%$

8. Do you personally know any students who paid a third party to do the work to get a study credits?

8.1. Yes

8.2. No

9. Please provide more information about the case:

10. Do you know how much these students pay for such a service?

10.1. I don't have these information's

10.2. Amount is:

11. If these cases have been reported to your University / College, have been taken any measures?

11.1. I don't have information that such cases have been reported to the university / college bodies

11.2. Yes, University has cancelled the credits

11.3. Yes, University has cancelled the credits of the candidate and person who provided the paid service has been used

11.4. No, no action has been taken by the University / College bodies. 
12. In your opinion, what are the reasons for the use of these services by students to obtain academic credit in this way?

12.1. They are not aware that such actions are illegal

12.2. Assessment methods applied at the College / University encourage students to pay a third party

12.3. Illegal

12.4. Others

13. Should the person who performs these services be punished?

13.1. Yes

13.2. No

14. Should students who pay for such services be punished??

14.1. Yes

14.2. No

15. What should the University / College change to prevent such actions?

15.1. To review student assessment methods

15.2. To offer many trainings and lectures about the preparation of such works

15.3. To organize awareness campaigns about the illegality of these actions

16. After completing this questionnaire, do you think you have a better understanding of the term "cheating contract" and its consequences?

16.1. Yes

16.2. Moderate

16.3. On average

16.4. Much more

16.5. No

Abbreviations

GBP: Grate British Pound; HEls: Higher Education Institutions; SPSS: Statistical Product and Service Solutions; THE: The Higher Education; UK: United Kingdom

\section{Acknowledgements}

We are very thankful to the respondents of our online questionnaire and all those that have helped us in collecting necessary data (academic staff of Kosovo), editing and provided us relevant recommendations.

\section{Authors' contributions}

Sabiha Shala has drafted the structure of the article, prepared the questions for the online questionnaire. She has done the desk research (collecting and analyzing the exiting relevant scientific articles), conducted the interviews and had written the whole article (abstract, introduction, literature review, discussion, recommendations, conclusion and references). Mimoza Hyseni-Spahiu has contributed on dissemination of the online question after having commented the list of questions. She has analyzed the answered received by the respondents and prepared the tables by using the SPSS program. She has read and commented the draft article especially the discussion part. Afrim Selimaj has contributed in preparation of online questionnaire and dissemination of it. He has collected and analyzed relevant part of legal and policy documents of the universities/colleges and other relevant institutions in Kosovo. He has read and commented the whole article. The author(s) read and approved the final manuscript.

\section{Authors' information}

Sabiha Shala teaches International and European Law and at the same time serves as Vice-Rector for Academic Affairs and Research at the University of "Haxhi Zeka" Peja, Kosovo. She is member of the University Committee for Ethics and Study Committee too. She used to work as a part time professor at the European School of Law and Governance. Formerly, Shala served as Chief Executive officer in the Agency for European Integration at the Kosovo Prime Minister Office, where she worked as a consultant on various projects with different international organizations such as: EU, UNHCR, UNDP, and OSCE. She obtained a Ph.D. from University of Nice Sophia-Antipolise in France. She holds an LL. $M$ in International and European Law from University of Riga, Latvia as well as an additional specialization in the field of diplomacy obtained from the Diplomatic Academy of Vienna. Her research interests include Academic integrity, European Integration, international law, International organizations and regimes, ect.

Mimoza Hysen Spahiu as Assistant Professor teaches Environmental; Protection Courses and at the same time is member of University Steering Council at University "Haxhi Zeka" in Peja, Kosovo as well as Member of Ethic Committee at this University. She used to work as Waste Senior Official at Kosovo Environmental Protection Agency 
for 8 years. She is part of several international projects in field of Environment. Her research interests include environmental protection, education for sustainable development, academic integrity etc.

Afrim Selimaj works as associate Professor and as Vice Rector for Budget, Finance and Infrastructure at the University "Haxhi Zeka" in Peja. He teaches several subjects in the field of economics. Before taking the position of Vice-Rector, he held the position of Vice Dean for Academic Affairs at the Faculty of Tourism, Hospitality and Environment Management at the University "Haxhi Zeka". In 2015-2017 he was engaged as a lecturer at the University of TetovaMacedonia. Within the academic and professional field, there have been many study visits to different countries such as Germany, Austria, Brussels, Italy, Ireland, etc. He is a holder of master's degree in economics from the University of Prishtina-Kosovo, as well as a doctorate in insurance, specifically in the concept of marketing development in insurance companies at St. Clement's University in Ohrid-Macedonia. From 2010 to 2013, he served in the position of Director for Property Issues at the Municipality of Peja in Kosovo. His research interests include Economic, Academic integrity, marketing, ect.

\section{Funding}

Authors will pay and the University of Haxhi Zeka will compensate them once the article is published in IJEl as it is indexed in Scopus and Web of Science.

\section{Availability of data and materials}

All the references that are available on internet have the link and are accessible.

\section{Competing interests}

All the authors declare that they have no competing interests.

Received: 3 July 2020 Accepted: 22 October 2020

Published online: 25 November 2020

\section{References}

AAB College (2020) University acts. https://aab-edu.net/per-aab/aktet-universitare/. Accessed 20 Jan 2020

Amigud A, Dawson P (2020) The law and the outlaw: is legal prohibition a viable solution to the contract cheating problem? JAEHE 45(1):98-108. https://doi.org/10.1080/02602938.2019.1612851?journalCode=caeh20

Boletini B, Molliqaj L (2017) Pazari me tema të diplomës. In: Report of NGO "ÇOHU", Prishtina http://preportr.cohu.org/sq/ hulumtime/Pazari-me-tema-te-diplomes-224. Accessed 16 Feb 2020

Bretag T, Harper R, Burton M, Ellis C, Newton P, van Haeringen K, Saddiqui S, Rozenberg P (2018) Contract cheating and assessment design: exploring the relationship. Assess Eval High Educ 44(5):1-16. https://doi.org/10.1080/02602938.2018. 1527892

Bretag T, Harper R, Burton M, Ellis C, Ph N, Rozenberg R, Saddiqui S, Haeringen K (2019) Contract cheating: a survey of Australian university students. Stud H Ed 44(11):1837-1856. https://doi.org/10.1080/03075079.2018.1462788

Bretag T, Mahmud S (2016) A conceptual framework for implementing exemplary academic integrity policy in Australian higher education. In: Bretag T (ed) Handbook of academic integrity. Springer, Singapore. pp 463-480. https://doi.org/10. 1007/978-981-287-098-8

Brimble M (2016) Why students cheat: an exploration of the motivators of student academic dishonesty in higher education. In: Bretag T (ed) Handbook of academic integrity. Springer, Singapore. https://doi.org/10.1007/978-981-287-098-8_58

Bytyçi A (2017) NGO coalition presents worrying research on integrity at University of Prishtina. https://prishtinainsight.com/ ngo-coalition-presents-worrying-research-integrity-university-prishtina/. Accessed 29 Dec 2019

Draper MJ, Newton PM (2017) A legal approach to tackling contract cheating? IJEl 13(11) https://edintegrity.biomedcentral. com/articles/10.1007/s40979-017-0022-5. Accessed 3 Dec 2019

Eaton SE, Chibry N, Toye MA et al (2019) Interinstitutional perspectives on contract cheating: a qualitative narrative exploration from Canada. IJEl 15(9) https://edintegrity.biomedcentral.com/articles/10.1007/s40979-019-0046-0. Accessed 17 Mar 2020

European Network for Academic Integrity (2020) 6th International Conference: Plagiarism Across Europe and Beyond 2020, in Dubai. European Network for Academic Integrity was supported by the Erasmus+ Strategic Partnerships project 2016-1CZ01-KA203-023949. Academic Integrity. eu. Brno, Czech Republic. https://www.academicintegrity.eu/wp/. Accessed 10 Aug 2020

Foltýnek T, Králíková V (2018) Analysis of the contract cheating market in Czechia. IJEl 14(11):1-15 https://edintegrity. biomedcentral.com/articles/10.1007/s40979-018-0027-8

Gazeta Blic (2018) Në Kosovë bëhet pazar me tema të diplomës, shiten deri në 250 euro. English: In Kosovo, it shows shopping with diploma, sold up to 250 euros. https://gazetablic.com/ne-kosove-behet-pazar-tema-te-diplomes-shitenderi-ne-250-euro/

Kosumi B, Leka D (2018) Plagiarism in Kosovo and its perception in Kosovo and Albania society. In: Razı S, Glendinning I, Foltýnek T (eds) Towards consistency and transparency in academic integrity. Peter Lang, p 43 https://www.peterlang com/view/9783631781593/xhtml/chapter04.xhtml. Accessed 2 Mar 2020

Krasniqi M (2015) Kosovo's cheating problem runs deep. Prishtina Insight https:/prishtinainsight.com/kosovos-cheatingproblem-runs-deep/. Accessed 28 Dec 2019

Lancaster T (2018) Buy An Essay - Essay Mills And Contract Cheating Pricing (Infographic) ThomasLancaster.co.uk. http:// thomaslancaster.co.uk/blog/buy-an-essay-essay-mills-and-contract-cheating-pricing/. Accessed 20 May 2020

Lancaster T (2020) Academic discipline integration by contract cheating services and essay mills. JAE https://link.springer. com/article/10.1007/s10805-019-09357-x. Accessed 15 Feb 2020

Medway D, Roper S, Gillooly L (2018) Contract cheating in UK higher education: a covert investigation of essay mills. Br Ed Res J 44(2). Wiley, England. https://onlinelibrary.wiley.com/doi/full/10.1002/berj.3335. Accessed 15 Feb 2020 
Newton PM (2018) How common is commercial contract cheating in higher education and is it increasing? A systematic review. Front Ed 3. United Kingdom. https://www.frontiersin.org/articles/10.3389/feduc.2018.00067/full. Accessed 21 Feb 2020

Rigby D, Burton M, Balcombe K, Bateman I, Mulatu A (2015) Contract cheating and the market in essays. JEBO 111:23-37. https://doi.org/10.1016/j.jebo.2014.12.019

Shala S, Leka D, Morganella T (2018) Plagiarism in Kosovo: a case study of two public universities. IJEl 14:12 https:// edintegrity.biomedcentral.com/articles/10.1007/s40979-018-0037-6

Sokol D (2017) Contract cheating and essay mills: how much proof do you need? THE. https://www.timeshighereducation. com/blog/contract-cheating-and-essay-mills-how-much-proof-do-you-need. Accessed 18 Oct 2020

Stoesz BM, Eaton EE, Miron J, Thacker EJ (2019) Academic integrity and contract cheating policy analysis of colleges in Ontario, Canada. IJEl 15:4 https://link.springer.com/article/10.1007/s40979-019-0042-4

UBT College (2020) Policies and Regulations. https://www.ubt-uni.net/sq/ubt/misioni-dhe-vizioni/politikat-rregulloret/. Accessed 12 Jan 2020

University of Applied Science (2019) Regulation for bachelor studies. http://www.ushaf.net/wp-content/uploads/2016/10/ Rregullore-per-studimet-themelore-Bachelor.pdf. Accessed 20 Dec 2020

University of Gjakova (UGJ) (2020) Regulations. https://uni-gjk.org/dokumentet/rregullore. Accessed 4 Feb 2020

University of Haxhi Zeka (UHZ) (2019) Regulations. http://unhz.eu/rregullore-2/. Accessed 29 Dec 2020

University of Kadri Zeka (UKZ) (2020) Important documents. https://www.uni-gjilan.net/universiteti/dokumentet-erendesishme/page/2/. Accessed 6 Feb 2020

University of Mitrovica (UMIB) (2019) Regulations. https://www.umib.net/rregulloret/. Accessed 20 Dec 2019

University of Mitrovica Isa Boletini (2020) Code of ethics. https://www.umib.net/wp-content/uploads/2020/02/Vendimaprovimi-i-Kodit-Etik.pdf. Accessed 2 Feb 2020

University of Prizren (2020) Regulations. https://uni-prizren.com/sq/rregulloret-dhe-dokumentet-upz\#breadcrumb. Accessed 21 Jan 2020

\section{Publisher's Note}

Springer Nature remains neutral with regard to jurisdictional claims in published maps and institutional affiliations.

Ready to submit your research? Choose BMC and benefit from:

- fast, convenient online submission

- thorough peer review by experienced researchers in your field

- rapid publication on acceptance

- support for research data, including large and complex data types

- gold Open Access which fosters wider collaboration and increased citations

- maximum visibility for your research: over $100 \mathrm{M}$ website views per year

At $\mathrm{BMC}$, research is always in progress.

Learn more biomedcentral.com/submissions 